\title{
14. \\ „KINESKIM ZIDOM ODVOJENI“. POLITIKE IDENTITETA, NEJEDNAKOSTI I ISKLJUČIVANJA U DESNIČINU ZIMSKOM LJETOVANJU
}

\section{Marina Protrka Štimec}

UDK: 821.163.42-311.6Desnica, V.

Izvorni znanstveni članak

Sažetak: Zimsko ljetovanje Vladana Desnice čita se kao roman „sukoba mentaliteta“, kao ogledan primjer autorova verizma (K. Nemec) te, u novijim tumačenjima (npr. D. Dukić, M. Sindičić Sabljo), kao imagološki zanimljiv, ali u konačnici modernistički superiorno nadređen vidljivim identitarnim polovima, odnosno kao iskaz „pesimističke, liberalno ironijske vizije sveta" (T. Brajović). Polazeći od spomenutih čitanja, u članku se upućuje na pripovjedne strategije kojima se autor služi kako bi upozorio na mehanizme proizvodnje razlika koje na individualnoj i kolektivnoj razini generiraju nejednakost i nepravedne društvene odnose, a koje su u romanu vidljive u fokalizaciji likova, njihovu međusobnom ophođenju te, u konačnici, načinu na koji se realizira središnja narativna linija teksta. Slijedimo li u tom smislu pomno osmišljene narativne postupke kojima se Desnica služi kako bi opisao strategije gradnje i održavanja „kineskih zidova“, binarnih razlika i kolonijalnog diskursa, od svakodnevnog ophođenja do praksi imenovanja, ovladavanja i supremacije u javnom diskursu, roman možemo čitati i kao izraz autorova kulturnog i društvenog angažmana. Bestijalizacija i imenovanje su, kao recipročne strategije, vidljive i kao sastavni dio individualnog imaginarija, ali i kolektivnih predodžbi i simboličkih društvenih praksi koje, na koncu, instrumentaliziraju i civilne i vojne vlasti. (Pre)imenovanja funkcioniraju kao strategija povezana $s$ aproprijacijom prostora i discipliniranjem i podčinjavanjem stanovništva, pri čemu postaje jasno kako se stereotipi ugrađuju u kolonizatorske politike. Baveći se urbicidom, ratnim razaranjima i krizom humaniteta, Desnica je u Zimskom ljetovanju uputio i na proizvodnju binarizama, esencijalizaciju i orijentalizam kao poluge hegemonijskih struktura vlasti, čime je posljedično inervirao neuralgijske točke onodobnog društvenog poretka. Obnovljenom aktualnošću, ovaj tekst i danas otvara mogućnost kritičkog razmatranja suvremenih politika identiteta, nejednakosti i isključivanja.

Ključne riječi: Zimsko ljetovanje, Vladan Desnica, orijentalizam, hegemonija, Morlaci, hrvatska književnost, identitet, imperijalizam 
imsko ljetovanje Vladana Desnice čita se i kao roman „sukoba mentaliteta“ i kao ogle-
dan primjer autorova verizma ${ }^{1}$. U novijim tumačenjima ${ }^{2}$ istaknut je imagotipski po-
tencijal teksta koji je, jasnim autorskim zahvatom, kako ističe Davor Dukić, nadiđen u korist općenitijih koncepata: prije svega filozofskih i svjetonazorskih. Okvirno, kako pokazuje, tematski svijet ovog romana razotkriva niz kolektivnih identiteta: 1) etničkih (talijanski/srpski/hrvatski), 2) konfesionalnih (katolički/pravoslavni), 3) jezičnih (slavenski/talijanski), 4) političkih (fašistički/četnički/partizanski) i 5) sociokulturnih (urbani/ruralni), od kojih je potonji jasnije naglašen i prepoznat. U cjelini, njihova brojnost i mjesto koje imaju u romanu pokazuju da je tema identitarnih politika, odnosno međusobno antagoniziranih perspektiva i identiteta u oblikovanju zajednice naročito važna za ovaj roman u cjelini - iako, prema Dukiću, dominantna „građansko-elitističko-kozmopolitska ideologija“, prema kojoj se prezire svaka identifikacija ispod razine svjetonazorskog, dovodi do nivelacije navedenih opreka, čineći Zimsko ljetovanje „imagotipski neeksplicitnim“3 ${ }^{\text {"romanom. }}$

Donekle srodno ovom Dukićevu zaključku, ali s polazišta iz kojeg se pojam ideologije vrlo specifično shvaća, Zoran Kravar smatra da je Zimsko ljetovanje kao dominantno pripovjedački roman - prije svega neideologičan. Tvrdi to istodobno upućujući na koncept ideologije kao „lažne svijesti“, odnosno „organizacijskog okvira“ za političku debatu i akciju, koji se najčešće oblikuje kao „skup ideja, najčešće svjetskopovijesnih prognoza, povijesno filozofskih uvjerenja i aktivističkih performativa kojima se osmišljava određeni oblik političkoga djelovanja“" Za razliku od autora poput npr. Miroslava Krleže, kako ističe Kravar, Vladan Desnica izmiče angažiranom diskursu - što najjasnije prepoznaje na sljedećim razinama:

1. među protagonistima romana nema intelektualaca, klase „iz koje moderna proza najčešće regrutira nositelje ili kritičare ideološkoga diskursa“"

2. pripovjedač romana ostaje „ideološki neutralan“ te „ne zapada u iskušenje da spoznajni doseg svojih likova ironizira i pokaže kao intelektualnu uskogrudnost“. Naime, prema Kravaru, „lociranje 'ljudske gluposti'“ u svijesti ovog ili onog društvenog sloja, kao i tome analogan, poučak o potrebi temeljite promjene društvenih odnosa i odgovarajuće

1 Krešimir Nemec piše da bi se Zimsko ljetovanje moglo „s obzirom na način prikazivanja, nazvati verističkim sociokulturnim mozaikom. U težnji za istinitošću i objektivnošću pripovjedač se rado zadržava na sumornu, neljudskom, nagonskom." Usp. Krešimir Nemec, Povijest hrvatskog romana od 1945. do 2000., Zagreb 2003., 112.

2 Usp. Davor Dukıć, „Nekoliko imagoloških opaski o Zimskom ljetovanju i Desničinim susretima“, Desničini susreti 2005. - 2008. Zbornik radova (ur. Drago Roksandić i Ivana Cvijović Javorina), Zagreb 2010., 149-156; Mirna SiNDičić SABLjo, „Predodžbe o ruralnoj sredini u Zimskom ljetovanju Vladana Desnice“, Fluminensia, 23/2011., br. 1, 131-142.

3 Dukić svoje razlaganje o Zimskom ljetovanju, tom Desničinu „najimagotipskijem djelu“, oblikuje s ciljem ilustriranja svojevrsne inkompatibilnosti Vladana Desnice (kao književnog i kulturnog znaka) i ključnih tema skupa i zbornika u kojem je tekst objavljen: tema ideologije vlasti i ideologičnosti teksta. Uz potrebne ograde zbog uopćavanja, Dukić ističe kako je Desnica zapravo ,građanski elitist i kozmopolit koji prezire identifikacije ispod razine svjetonazorskog (filozofskog)“, pa je, prema tome, „etničko, jezično i konfesionalno za njega akcidentalno i kao takvo ga zapravo ne zanima." Drugim riječima, iako je pitanje identiteta operabilno „u analizi semantike njegovih djela“, on zapravo „tradicionalno shvaćanje kolektivnog identiteta demistificira, ironizira, razgrađuje.“ Stoga, kako ističe, kanonizacija Vladana Desnice nije utemeljena „u njegovu odnosu prema stereotipnim/imagotipskim predodžbama kolektivnih identiteta već prije u njegovu književnom otporu tim, inače legitimnim, strategijama poopćavanja."

4 Zoran Kravar, „Zimsko ljetovanje Vladana Desnice pod ideološkokritičkim lećama“, Desničini susreti 2005. - 2008. Zbornik radova (ur. Drago Roksandić i Ivana Cvijović Javorina), Zagreb 2010., 10-11.

5 Isto, 13. 
„transformacije mentaliteta“ predstavlja „otvoreno ideologičan“ govor ${ }^{6}$, što se može prepoznati npr. u Krleže, ali ne i u Desnice.

3. rat kao tema ostaje „na metonimijskoj razini“, „prisutan onoliko koliko je odgovoran za njihov trenutni inkomoditet“, „odsutan kao političkopovijesni događaj“. „Ratna zbivanja predviđaju se uglavnom s obzirom na njihovo moguće trajanje, a likovi i njihovi kolektivi ostaju nesvrstani i kad je posrijedi ishod rata. Ne znamo ni kakav je bio njihov odnos prema fašističkoj vlasti u Zadru kao dijelu Kraljevine Italije." Skandiranje Ernesta Donera u fašističkoj paradi ili odlazak građana na obvezno okupljanje koje u selu organiziraju četnici nije znak njihova političkog opredjeljenja, već svjedoči „o njegovu malograđanskom oportunizmu“".

Instruktivno je Desnicu uspoređivati i s Krležom, kako to čini Kravar ili još detaljnije Tihomir Brajović koji je svojoj analizi pridružio i Andrića ${ }^{8}$ - ali samo ako nam baždarenje na naglašene ironijske valere Krležina pisma ne zakrije nešto istančanije, no svejedno vidljive i, za interpretaciju Desničina teksta, izuzetno važne - ironijske odlomke ovog romana. Znakovito je, naime, da Kravar prepoznaje Desničin manevar kojim se tema rata i odnosa likova prema, primjerice, fašizmu kao neizbježnoj referenci pretvara u temu koja apostrofira „inkomoditet“ likova i njihov „malograđanski oportunizam“ - odustajući od ekspliciranja „političko-povijesnih“ reperkusija pojedinih „ideoloških opcija“ koje su usmjeravale povijest 20. stoljeća. Pritom, ipak, taj autorski postupak tumači kao „ideološki neutralan“, odnosno, slično kao i Dukić, nadređen mogućim pozicioniranjima unutar ili prema, lijevim, desnim ili centrističkim ideološkim pozicijama.

Nasuprot takvom tumačenju, danas bismo Zimsko ljetovanje mogli čitati kao roman koji - upravo prema spomenutom opisu kojim se, s one strane navedenih političkih aproprijacija - na scenu postavljaju mehanizmi proizvodnje i održavanja razlika između različitih skupina, u ovom slučaju građana i seljaka, civiliziranih, $s$ jedne, te potlačenih i obespravljenih s druge strane. Modernistička Desničina antropologija, kako je naziva Vladimir Biti ${ }^{9}$, koja zahvaća više, šire i načelnije od pojedinačnih slučajeva i odnosa, može se u ovom tekstu prepoznati u potrebi razgradnje kolektivnih identiteta na koju je u svom osvrtu upozorio Dukić, ali i u nastojanju za opisivanjem i rastvaranjem mehanizama njihove gradnje i održavanja.

Tema sela koje je „kineskim zidom“ (Desnica) odvojeno od grada u Zimskom ljetovanju realizirana je nizom postupaka u kojima postaje vidljivo da se prividna distanciranost i verizam pripovjedača udružuju s ironijskim iskazima koji upućuju na moralne, kulturne, pa u konačnici i političke reperkusije tih isključivanja zasnovanih na komoditetu, inertnosti i oportunizmu privilegiranih društvenih skupina - u ovom slučaju građana.

\footnotetext{
Isto.

7 Isto.

8 „Beletristička ostvarenja koja su trojica pisaca istodobno publikovala svojim ukupnim ustrojstvom stoje“, ističe Brajović, „u napregnutom i unekoliko kontroverznom odnosu prema normativno proklamovanim vrednostima i, posebno, prema praktično ostvarivanim konstelacijama i postojećim porecima te povesno-političke zajednice." Tihomir Brajović, „Ironija i kolektivna memorija: Desnica, Krleža, Andrić, Desničini susreti 2005. - $2008 ., 35$.

9 Vladimir Bıтı, Doba svjedočenja. Tvorba identiteta u suvremenoj hrvatskoj prozi, Zagreb 2005., 171.
} 
U nastavku članka uputit ću na pripovjedne strategije kojima se autor služi kako bi upozorio na mehanizme društvene proizvodnje razlika koje na individualnoj i kolektivnoj razini generiraju nejednakost i nepravedne društvene odnose, a koje su u romanu vidljive u fokalizaciji likova, njihovu međusobnom ophođenju te, naposljetku, u načinu na koji se realizira središnja narativna linija teksta.

Prepoznatljiv vremenski i prostorni okvir romana: Drugi svjetski rat od kapitulacije fašističke Italije i prvih savezničkih bombardiranja Zadra ujesen 1943. do ranog proljeća 1944. godine - Zadar i srpsko selo Smiljevci, udaljeni petnaestak kilometara, naglašene socijalne teme i realistički „objektivni“, tzv. sveznajući pripovjedač u trećem licu jednine tumačeni su kao izraz autorskog postupka koji je distanciran i superioran, oslobođen dosega tzv. „primijenjene književnosti“ kako ju je, ne bez gorčine, sam Desnica nazvao u svojim zapisima u Kolu. Tako shvaćen modernistički autorov univerzalizam tumačio se izvan okvira, motivacije ili neposrednog angažmana u društveno-povijesnom kontekstu. Unatoč tome, promotri li se iskaz tog „distanciranog“ pripovjedača, može se vidjeti kako su od samog početka njegova objektivnost i distanciranost zapravo svjesno hinjeni i da su opisi likova u prvom redu njihova fokalizacija - na strateškim mjestima obojeni suptilnom ironijom, bezglasnim čuđenjem ili tek znakovitom šutnjom.

Tako već na prvim stranicama romana pratimo skupinu građana u njihovu zbjegu na selo, pri čemu se taj susret s konkretnim prostorom i ljudima sudara (ali zadugo ne razbija) o stereotipne slike koje su donijeli sa sobom. Kao istaknuti fokalizatori tih uvriježenih slika poslužili su Lizeta i Ernesto Doner, bračni par koji će na kraju romana upravo na selu doživjeti osobnu tragediju. Njihov je pogled na selo postupno karikiran, unatoč „verizmu“ i distanciranosti pripovjedača koji na uvodnim stranicama romana ističe da je selo za građane terra incognita, mjesto bez značenja, od kojeg kao da su „odijeljeni kineskim zidom ili pojasom pustoši“, hiljadama, a ne petnaest kilometara ${ }^{10}$.

Njihovo je putovanje, kao i boravak na selu, obilježen egzotizacijom tog prostora i njegovih stanovnika. U naivnoj Lizetinoj predodžbi selo je nepresušni izvor „pilića, purana, pršuta i vina, i gdje se pred Uskrs ovce dadu na posao da nakote dovoljno janjaca, a kokoši da snesu dovoljno jaja“. U tom obilju hrane koje je, adekvatno klišeiziranoj predodžbi, inscenirano kao kolaž zelene livade s makovima i potočićem po sredini, ima svega - „ali nadasve mlijeka! U toj njenoj predstavi, mlijeko je naviralo nepresušno, bujalo i pritiskalo kao u grudima novorotkinje, teklo potokom i rijekom, nemjereno i nezaustavljivo, odlijevalo se u kablice, zdjele, čanke i čančiće, a nikako da mu se postavi brana i uredi otjecanje. ${ }^{\text {"11 }}$. Pri tome su, dosljedno logici imperijalističke imaginacije, ljudi na selu prikazani kao „podmukli i lukavi, i imaju uvijek prljave ruke (...) prilično smiješni; useknjuju se prstima, i treba im dobro vikati, jer su malo nagluhi, od prljavštine koja im se nakupila u ušima. Žive kukavno, ali tome su krivi sami jer su krajnje neumješni i nesnalažljivi “" ${ }^{\text {"12 }}$ ali ipak „u svakoj prilici gledaju da podvale građanima“. Na selu su najgore zmije, „podmukle, kao i njihovi

\footnotetext{
10 Vladan Desnica, Zimsko ljetovanje, Zagreb 1998., 5.

11 Isto.

12 Isto, 5-6.
} 
gospodari seljaci“"13, iako se treba čuvati i komaraca, kojih je sva sila ljeti i od kojih se dobiva malarija, jednako kao što se dobiva i kad se „smoče noge“.

Diskretan humor ovih rečenica pripovjedač dograđuje opaskom kako je, za razliku od Lizetine, Ernestova „predodžba sela bila nešto stvarnija i potpunija“, što zapravo znači tek da u obzor njegovih stereotipa ulaze ekonomski odnosi na selu, pri čemu on razlikuje obične seljake $i$,plemenske poglavice "14, podjednako uvjeren da su seljaci majstori pretvaranja i cjenkanja, da su jedni „neuki i zaostali“, a drugi „previše lukavi i prevejani“, ali da svi, i primitivni i pokvarenjaci, „od očiju bijelog čovjeka“15, kriju dobre i autentične stvari, poput „bačvice 'pravog, nepatvorenog domaćeg vina'“. Nešto kasnije, kad započne izbjeglički život građana, njihovo „zimsko ljetovanje“ na selu - perspektiva se neće bitno promijeniti. $\mathrm{Na}$ selu se građani drže zajedno, čuvajući svakodnevnu gradsku rutinu, kolektivna stajališta i poglede: „Izbjeglice su pomalo tonuli (sic!) u selo i upoznavali se s njim. Potvrđivala su se njihova ranija mišljenja o seljačkoj prljavosti, lukavosti i spremnosti na tuđe bijede. Osim toga, pokazalo se da su seljaci, u stvari jako ograničeni i da se uvijek i svemu cere kao crnci. ${ }^{“ 16}$, „smiju se drugima, a sami govore tako da ih nikako ne možeš razumjeti“. Pripovjedačeva mimikrija u fokalizaciji i imenovanjima ostaje tek na razini na kojoj se detektira isključivost, obilježavanje i egzotizacija drugoga. Zanimljivo je, iz perspektive „ideologičnosti teksta", primijetiti da se analogna identifikacija sela s primitivizmom ili urođeničkim kulturama ponavlja u trenutku kad četnici zajedno s vojvodom Duletom prisiljavaju stanovništvo na okupljanje i polaganje zakletve: „činilo im se da prisustvuju nekoj ritualnoj

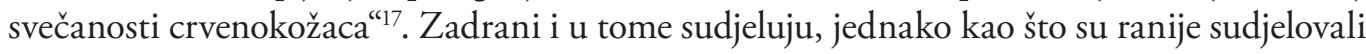
u fašističkim mimohodima na ulicama grada - iz inercije, straha i ignorancije, ali s jednakim otporom i indignacijom prema „tim stvarima“"18 koje generira selo.

Ovakva se njihova razdvojena i udaljena gledišta ne iskupljuju u istaknutoj narativnoj instanciji koja bi donijela adekvatan pravorijek ili ponudila jasniju perspektivu u razumijevanju. Pripovjedač ostaje diskretno iza izrečenog, ponegdje čak bez pogovora propušta njihovo gledište, što je navelo kritičare i književne povjesničare da ovaj roman čitaju kao „objektivnu“ sliku društva ili „neideologično“ ili „neutralno“ ocrtavanje stvarnih regionalnih društvenih problema s jedne strane, a s druge kao pesimističnu i rezignantnu sliku tog istog društva. Navedeni, pak, citati potvrđuju vidljiv Desničin angažman kojim sustavno pristupa raščlanjivanju mehanizama i dinamike gradnje te održavanja društvenih razlika koje niču na osobnoj razini, udružuju se s kolektivnim predodžbama, materijaliziraju simboličkim društvenim praksama i, na koncu, instrumentaliziraju ulazeći u djelokrug vlasti.

Jedna je od praksi snažnog simboličkog učinka praksa imenovanja koju Desnica pokazuje na nekoliko slučajeva mijenjanja ili zadržavanja imena. Ponajprije, dolaskom na selo, mala Mafalda postaje Špižmica ${ }^{19}$ - dobivajući od pomodnog talijaniziranog imena loka-

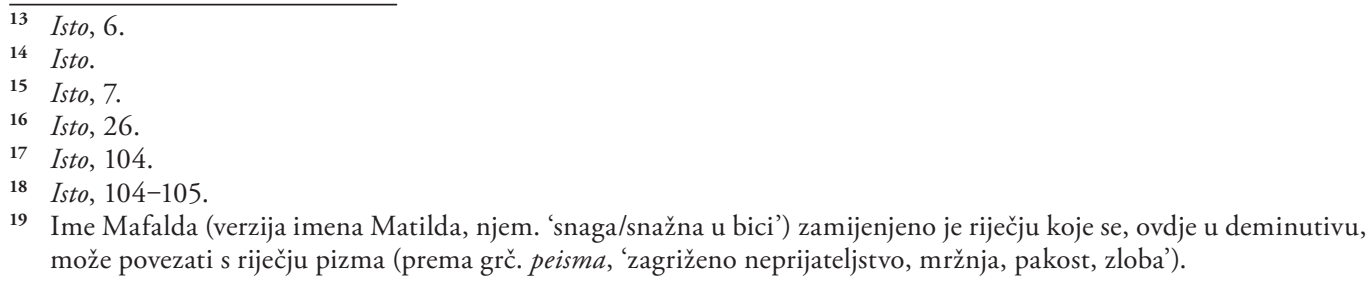

19 Ime Mafalda (verzija imena Matilda, njem. 'snaga/snažna u bici') zamijenjeno je riječju koje se, ovdje u deminutivu, može povezati s riječju pizma (prema grč. peisma, 'zagriženo neprijateljstvo, mržnja, pakost, zloba'). 
lizirani deminutiv, onomatopejski, slavenski, čime se pokazuje kako se i njezin identitet mijenja i povezuje s tim prostorom u kojem raste i u kojem će tragično skončati, a prema kojem odrasli pripadnici skupine zadržavaju odmak. U šestom se poglavlju to preimenovanje ovako opisuje: „Otkad su ovdje na selu, zvali su je nadimkom koji joj je od milja nadjenuo otac još u Zadru: Špižmica. Ime Mafalda ostavili su za bolja vremena - nije se priličilo da takvo ime vuče svoje grimizne skute po seoskoj prašini. “20 (istaknula M. P. Š.). Ovaj završni dio rečenice, neka bude zabilježeno, upotpunjuje niz duhovitih pripovjedačevih komentara kojim se katalogiziraju stavovi i postupci građana u odnosu na selo kao vlastito Drugo.

Strategije i značenje imenovanja pojavljuju se kao tema vrlo brzo nakon ovoga: u devetom poglavlju u kojem se uvodi lik Mafaldina/Špižmičina usmrtitelja: prasca Miguda, „glavne ličnosti u Ićanovu kućanstvu“21. Imenovanje životinje ovdje znači, kao što čitamo već u prvoj rečenici poglavlja, poosobljavanje: postajanje ličnošću.

„Prase obično nema ličnog imena. I dobro je što je tako. Jer ime uspostavlja izvjesnu bliskost između životinje i čovjeka; po njemu se ona izdiže iz bezimenog životinjskog bića, stremi k izjednačenju s čovjekom, dobiva svoje posebno lice, svoju ličnu istoriju; poznamo joj sklonosti, i narav, i navike, pamtimo joj doživljaje; postaje nam društvo, s njom nas vežu zajedno proživljeni časovi - ukratko, postaje osoba; doduše, još ništa, beslovesna osoba - ali osoba! ${ }^{22}$.“

Kao svojevrstan refren, od prve rečenice navedenog citata, u sljedećim se paragrafima ponavlja: „Dobro je što prase nema imena! (...) Da, dobro je da je prase bezimeno. Ali eto, Ićanovo je prase imalo svoje ime." Tim se imenovanjem razotkrilo sve ono što se bezimenošću inače želi nadvladati: emotivan odnos; čovjek se prasetu, kao i svakoj drugoj životinji, „lako priljubi“, „u dnu njegove zjenice tinja iskra prave ljudske tuge“, pa je ta spoznaja „čista ljudska trepavica“ u ljigavoj masi hladetine koju slasno jedemo kadra „da olabavi viljušku u ruci." Imenovanjem prase ulazi u prostor čovjekova emotivnog i spoznajnog povezivanja te time utječe na prosuđivanje i postupanje. Migud, kao „glavna ličnost“ Ićanova kućanstva, „sam spomenik svinjskom rodu“, imenovanjem dobiva povlašteno mjesto ne samo u vlastitom dvorištu, nego i u proširenoj seoskoj zajednici, postajući tako točkom njezina ovjeravanja - u međusobnom ophođenju članova te, u konačnici, u načinu na koji se dinamika tih odnosa prelama na najslabijim članovima društva, u ovom slučaju na djeci i životinjama. ${ }^{23}$

\footnotetext{
V. Desnica, Zimsko ljetovanje, 28.

Isto, 42 .

Isto.

23 Životinje i djeca pojavljuju se u najstrašnjijm prizorima rata: bombardiranje koje je dovelo do pokolja djece iz vrtića, zatečenih u šetnji: „Neke je eksplozija bacila visoko u zrak pa su padajući s visine zapeli na telegrafske žice pored puta; vise tako dječja tjelešca, presamićena preko žica kao djetinje haljinice izvješene na sušenje." (isto, 15). Iz prvog posjeta gradu smiljevačke izbjeglice donose ,jednu sliku koja se pamti“: „,iza zatvorena prozora neke puste magaze, verala se nemoćno po glačini stakla izgladnjela i užasno omršala mačka, iznemoglo mjaučući. Patnja je dala potresan, gotovo ljudski izraz njezinim zjenicama, i čovjeku je bilo nelagodno ostati skrštenih ruku pred tim pogledom. (...) Rješenje je bilo jednostavno: razbiti staklo - i životinjica je spašena. Ali ljudi su se bojali..." (isto, 31-32; istaknula M. P. Š.). „Ljudski izraz“ mačjih zjenica i neljudsko okretanje glave od mogućnosti pomaganja nemoćnom umirućem biću pojavljuje se u romanu kao nastavak rečenica koje opisuju zaobilaženje ruševina i okretanje glave od stradalih koji su pod njima zatrpani i s puno nade čekaju pomoć. Isto, 15, 23.
} 
Imenovanje je i postupak (pre)označavanja i zaposjedanja značenja, na što upućuje epozoda fašističke kolonizacije prostora - u trenutku kad nova vlast traži adekvatno ime za Smiljevce. U proizvodnji značenja i raspodjeli administrativne, vojne i simboličke moći, fašističke vlasti otvaraju građevine, mjesta sjećanja, proizvodeći i lokalne heroje: za ovu potrebu fabriciraju lik Emilia Placcidruga, kojeg su svi poznavali kao lokalnog probisvijeta Milu Plačidruga. Kao „krnjatci uspomena“ iz vremena njihove vladavine ostaju ruševine izgorjele vinarske zadruge $s$ ambivalentnim natpisima koji svjedoče o represiji i aktivizmu tog minulog doba, a koji su se, zajedno s nekim drugim implikacijama teksta, mogli iščitati i kao neugodna aluzija na represiju i angažman prvih poslijeratnih godina: $C H I N O N$ Ė CON NOI AVRÀ DEL PIOMBO! ('Tko nije s nama, dobit će metak!') i DISSODATESMAGGESATE! ('Iskrčite ledinu, preorite ugar!').

U tom ho-ruk osvajanju prostora, u Smiljevcima će ostati zabilježen višestruki neuspješan pokušaj talijaniziranja imena sela: od Borgo Mirtillo (za što uskoro saznaju da je zapravo borovnica, a ne smilje), preko Timeto (što se ispostavi da je majčina dušica) do $\mathrm{Gnafalio}^{24}$. Sva su ova (pre)imenovanja povezana s aproprijacijom prostora kojim se nova fašistička vlast koristi kao poligonom za održavanje poretka i discipliniranje podanika, podupirući uvriježene stereotipe na kojima će graditi vlastite kolonijalne pretenzije. Kada uz pomoć lokalnog znanstvenika, prof. Bogdanija, u selo dolazi fašistički federale u potrazi za zapretanom poviješću i orijentalnim tragovima, Bogdani će svom sugovorniku tumačiti kako je od Turaka na ovim prostorima ostala „sva sila turskih riječi, izraza i običaja“, ali i običaj sadnje jablanova koji „podsjećaju na turske minarete“, pa su Turci „na svojim pohodima, u nedostatku minareta, ukujisali s nekakve platformice načinjene u granju jablana. Taj podatak, dotad, kako reče Bogdani, nezabilježen u nauci, federala je živo zainteresirao“ jer je on volio „zornu povijest, dakle, jasnu i opipljivu, a ne maglovitu i nejasnu kakva mu se činila istorija tog kraja“. Pred njom i među ovim ,žutim življem s ponadulim dalcima što još kusa drvenom žlicom i ravnodušno zuri u auto koji promiče“ 25 među ženama „samojedski niska čela koje se pred kućom na suncu bištu" njegova prosvijećena, kolonizatorska misija pod okriljem vojne supremacije doživljava besmisao vlastitih nastojanja ${ }^{26}$ : „Ja uopće ne razumijem što mi tu tražimo! Zašto se razlijećemo po svijetu i hoćemo da usrećujemo ljude i narode proti njihovoj volji, mjesto da sjedimo kod kuće i liječimo naše vlastite rane i bijede? A mi, eto, po Evropi i bližoj Africi gradimo drugima dobre drumove kroz bespuća, kao da smo postali neko poduzeće za asfaltiranje cesta! "27.

Federale se, slično kao i kulturni došljaci sa zapada ili iz grada, bilo da je riječ o prof. Bogdaniju ili građanima „srednje ruke“, prema Smiljevcima i cijelom kraju odnosi ignorantski, promatrajući taj prostor kao praznu, bijelu točku koju treba osvojiti i ispisati. ${ }^{28}$

24 Isto, 55-56.

25 Prema Saidu, orijentalistička predodžba „primitivca“ uključuje: izdvojenost, nijemu ravnodušnost, žensku penetrabilnost i nemarnu povodljivost. Orijentalac je, kao takav, pasivan, traži zapadnu pozornost, pa čak i spas od Zapada, a povezan je s rubovima zapadnog društva: ženama, luđacima, siromašnima i djecom. Edward SAID, Orijentalizam (prev. Biljana Romić), Zagreb 1999., 261-299.

26 V. Desnica, Zimsko ljetovanje, 63-64.

27 Isto, 64.

28 Orijentalizam se, kao oblik diskursa koji izražava i predstavlja europsku materijalnu civilizaciju, kako pokazuje Edward Said, ostvaruje na temelju potpore ustanova, vokabulara, znanosti, likovnosti i doktrina. Kao način mišlje- 
Pasivnost, nerazumijevanje ili otpor lokalnog stanovništva u njemu, slično kao i u francuskim konzulima čiji boravak u Travniku Ivo Andrić opisuje u samo nešto ranije objavljenoj Travničkoj hronici, izaziva rezignaciju ${ }^{29}$. Orijentalizam došljaka vidljiv u esencijalizaciji vlastite i tuđe kulture, proizvodnji binarizama i kolonijalnom patronatu koji hegemoniju opravdava vlastitom superiornišću u Zimskom ljetovanju postaje središnja tema koju Desnica eksplicira na nekoliko razina.

Njegovi građani, u osobnim i kolektivnim relacijama prema selu, jednako kao i znanstvenici ili predstavnici vojne ili civilne vlasti ${ }^{30}$, generiraju razlike između vlastite kulture i kulture/prostora Drugoga - ulažući u, na početku definiran, „kineski zid“ između vlastitog identiteta i onog Drugog. U ranije spomenutom članku, koji je nastao kao reakcija na osuđujuće kritike, Desnica će stavove i postupke Zadrana ovako rezimirati:

„Ni za časak neće pomisliti da im to selo i sada, za tog 'zimskog ljetovanja', ustvari vraća zlo dobrim, i da bi im možda bila dužnost da u toj zemlji ostanu i da za njeno dobro nešto porade. Jedini im je poriv - bježati, iskopati se iz tog pakla, zatvoriti oči pred njegovim strahotama i izbrisati mučnu uspomenu iz svog pamćenja. Dok se najzad ta ista stvarnost ne sruči svom svojom strahotom na glavu najnevinijeg od njih - baš kao što se vjekovima sručavala na nevine glave čitavog tog naroda. Pa i tada će uzrok tim prilikama građani nalaziti u 'živinstvu' tog čovjeka, a uzrok živinstvu tog čovjeka - u 'volji Svevišnjega'!“31

Živinstvo čovjeka i čovječnost živine pojavljuju se kao motivi romana u nekoliko navrata:

a) kod bombardiranja Zadra: zaborav drugih, čak i najbližih, okretanje glave od stradalih pod ruševinama dovodi do zaključka o tome kakva je čovjek živina ${ }^{32}$;

b) povezano $s$ time: nevidljive, a prisutne ljudske žrtve pod ruševinama grada dobivaju svoje lice $\mathrm{u}$ ispaćenom, ljudskom pogledu izgladnjele mace koju vide kroz prozor, zarobljenu u srušenom magazinu - životinjsko lice kao ljudsko osvjetljava neljudskost čovjeka ${ }^{33}$;

nja reproducira se mrežom znanja i predodžbi, a počiva na ontološkoj i epistemološkoj distinkciji između „Orijenta“ i „Okcidenta“. E. SAID, Orijentalizam, 8, 122-144.

29 Andrićev narativni angažman u razobličavanju orijentalističkih stavova došljaka te konceptualizacija Bosne kao heterotopijskog mjesta na kojem se sudaraju stavovi i prakse obilježavanja i isključivanja vidljiv je, nimalo slučajno, u romanu objavljenom 1945. godine. Usp. Marina Protrka Štimec, „'Ovo tursko i iracionalno’. Orijent kao bolest, otrov i lijek u Travničkoj hronici Ive Andrića. "Mjesto, granica, identitet, Prostor u hrvatskoj književnosti i kulturi (ur. Lana Molvarec), Zagreb 2014., 129-146.

30 „Morlakija“ je za došljake divlji i neispisan prostor; njome su, u potrazi za vlastitim ciljevima, kako ističe Desnica (ne preuzimajući pritom ovaj izraz), „krstarili“ ne samo književnici nego i drugi „predstavnici kulture - od trijangulacionih i agronomskih ekipa i malarloloških komisija do geografa, arheologa, etnografa, filologa (...) oni su popisali svaki kamen, zabilježili svaku jezičnu apartnost - ali skoro nitko nije obratio ozbiljniju pažnju na živog čovjeka i na njegova životna pitanja." (V. Desnica, Hotimično iskustvo: diskurzivna proza Vladana Desnice, Zagreb 2005., 135) Isto, 137.

32 U trenutku kad postane svjestan da je, zastrašen naletom bombardera, zaboravio na svoje ukućane, Ernestov sugovornik Minuči na početku romana ,izvali... naoko bez veze“: „Ma l’uomo e proprio una bestia!“ (V. DesnicA, Zimsko ljetovanje, 16), kvalifikativ koji će se ponoviti i nakon tragičnog raspleta na samom kraju romana.

33 Lice Drugoga označava, prema Emmanuelu Lévinasu, potpunu izloženost, golotinju, bespomoćnu otvorenost koja po sebi postaje obilježjem etičkog odnosa. Pogledi životinja u Desničinu romanu poprimaju obilježja upravo levinasovskog lica: njihova golotinja, pravednost/iskrenost/ispravnost i izravnost suprotstavljene su maskiranosti, himbenosti i posrednosti koje se pojavljuju u definiciji dramskog (Ducrot) ili gramatičkog lica (Benveniste). To znači, kako ističe Vladimir Biti, da u ovom slučaju etički odnos s Drugim stavlja u pitanje, da mu oduzima privilegiranu poziciju moći. Iz ove je perspektive zanimljivo da je tragičan kraj djevojčice Mafalde/Špižmice obilježen upravo unakaženjem lica, što se u Lévinasovoj filozofiji (razumije se, u figuralnom smislu) tumači kao imperijalno zaposjedanje Drugoga: 
c) u karakterizaciji i imenovanju prasca Miguda: „glavne ličnosti u Ićanovu kućanstvu“"34: ljudska tuga u životinjskim očima - implicirana neprihvatljivost ubijanja životinja;

d) na samom završetku romana, kad Zadrani, okupljeni oko ucviljene obitelji, komentiraju prilike i život seljana nazivajući ih živinama.

Čine to, znakovito, nakon dugo vremena, talijanskim jezikom:

"- Dio mio, che condizioni! I vive proprio come le bestie. ${ }^{\beta 5}$ - uzdahnu šjor Karlo.

- E no xe altro che bestie ${ }^{\beta 6}$ - dometne Narcizo Golob.

- Perché $i$ xe bestie? - upita djetinjski zainteresiran slaboumni Bepica vukući oca za rukav.

(...)

- Papà, ma perché $i$ xe bestie? ${ }^{37}$

- Perché cosi Iddio li ga creà! ${ }^{38}$ - izreče odmjereno, dubokim glasom šjor Karlo. “39

Kao odgovor na ovo konačno odvajanje građana koji osuđuju seljane zbog njihova života koji je doveo do tragedije, oglašava se „s pobunom“ (!) Ernesto, otac stradale djevojčice, riječima koje ponovno diskretno naznačuju i kritiku i obrat, završavajući njima ovo poglavlje i cjelokupnu temu „zimskog ljetovanja“. Njegov gorki uzdah: „Ah, 'sto vostro Dio, 'sto vostro Dio!“ ('Oh, taj vaš Bog, taj vaš Bog!')“ - povezuje sve one unaprijed zadane slike osobne i kolektivne ignorancije, zaobilaženja vlastite odgovornosti i sudjelovanja u promatranju tuđe patnje i njezine društvene proizvodnje u protest koji apostrofira prešućivanje vlastite odgovornosti za nesreću (tuđu i vlastitu) te, uz to, otvara mogućnost izokretanja ili izmicanja hegemonijskim obrascima koje su ova razdvajanja generirala.

Bestijalizacija Drugoga dio je strategija na kojima se zasniva hegemonijski odnos u različitim društvima. Sve su hijerarhije zasnovane na „dominaciji savršenstva nad nesavršenstvom, sile nad slabosti, iskazane vrline nad porokom“, zbog čega „tijelo treba biti podvrgnuto duši, robovi svojim gospodarima, a žene svojim muževima “40. Metonimijski lanac ovih nasuprotnosti izložen je i u odnosima koje apostrofira i ovim svojim romanom Vladan

predodžbom, mišlju, tematizacijom ili prikazom. Unakazivanje je „politička neutralizacija etičkog izazova“. V. BıTı, Doba svjedočenja, 72-73.

34 V. Desnica, Zimsko ljetovanje, 42.

35 „Bože moj, kakvih li prilika! Žive baš kao životinje!“ (prijevodi su ponuđeni u bilješkama romana, op. M. P. Š.).

36 „Pa i nisu drugo nego životinje!"

37 "Tata, ali zašto su životinje?“ Indikativno je da pitanje postavlja dijete, i to „slaboumno“, čiji imaginarij do apsurda dovodi logiku obilježavanja, praksu dominantne kulture (građani, odrasli, muškarci): „Pred očima su mu bljesnule slike iz slikovnice Vesele životinje: lisica s visokom kragnom i dirigentskom palicom, slonovi u isprutanim kupaćim gaćicama što nose jaje na drvenoj žlici..." (V. Desnica, Zimsko ljetovanje, 148). Dječje „nevino“ pitanje, ponovno „kao usput“, komentira i donosi sud, najprije upućujući na besmislenost obilježavanja, a zatim - i kroz ikonografiju slikovnice - na „civiliziranje“ životinjskog u procesu edukacije, „očovječenja“ ili odgoja djece. Ovome treba dodati i još jedan suptilni pomak koji toj replici dodaje Desnica: dijete je opisano kao „slaboumno“, čime se njegov komentar dodatno potencira te se unosi perspektiva marginalizacije i isključivanja hendikepiranih, koji su, u ovom kontekstu, dvostruko marginalizirani. Tom svojom kondicioniranošću Bepica se oglašava s one strane binarne logike odraslih, kao dio marginaliziranog i time povezanog sa svijetom koloniziranih: on je jedan od „nepravnopravnih“", potlačenih: seljaka, djece, životinja. Usp. E. SAID, Orijentalizam, 261-299, a detaljnije o relacijama moći i konceptu „prirodnog“ u pristupu djeci i životinjama u: Matthew Cole i Kate Stewart, Our Children and Other Animals. The Cultural Construction of Human-Animal Relations in Childhood, Ashgate 2014.

39 V. Desnica, Zimsko ljetovanje, 148. 
Desnica, pokazujući kako se „građani“ služe opravdanjima kakvima se koriste kolonizatori kad opravdavaju rat i podjarmljivanje starosjedilaca njihovom životinjskom prirodom, kanibalizmom i žrtvovanjem ljudi - ili, pak, jednostavno primitivizmom i neciviliziranošću. Desničin pripovjedač u Zimskom ljetovanju, fokalizirajući stavove i promišljanja „građana“, pokazuje da je njihov imaginarij zasnovan na odvajanju vlastite civiliziranosti od bestijalnosti, barbarizma i morlakizma seljaka. Njihov je stav autorskim ironijskim i narativnim zahvatima prokazan kao dio prepoznatljivih strategija kojima klasno, rasno, rodno ili regionalno povlaštene skupine izgrađuju i podržavaju hegemonijske mehanizme društva. Pritom su dio istog kompleksa pasivnost i okretanje glave od vlastite odgovornosti za stradanja i nepravde zajednice koje Desnica apostrofira u prvim poglavljima romana, jasno razgraničavanje linije razdvajanja između "plemenskih poglavica“ i „bijelog čovjeka“ u središnjem dijelu ${ }^{41}$ te zaključne opaske o bestijalnoj naravi i oklonostima života u „Morlakiji“. Svi se, na različite načine, ugrađuju u proces kojim se privilegirana, gradska kultura održava u svojoj supremaciji nad obespravljenom i pasiviziranom seoskom provincijom ${ }^{42}$.

Pri tome, dakako, Desnica svoj postupak metonimijski širi izvan lokalnih okvira u koje je postavljena radnja romana. Njegova je ironija, među ostalim, usmjerena prema konceptima kulturnopovijesnog pamćenja, kako je to pokazao T. Brajović ${ }^{43}$, ali i prema svim oblicima homogenizirajućih političkih i društvenih praksi te isključujućih identiteta. Interes je njegova teksta ovdje, kao i u drugim slučajevima, izvan zadanih okvira: u „pustoši stvari“ iz kojih, kako piše u metanarativnom petnaestom poglavlju romana, „požudno rastu uspome$n e^{\text {“44 }}$. Zato je, kako pred kraj romana ističe Šjor Karlo, posve jednako gdje se odvija radnja ili stječe iskustvo: „Ljudi su ljudi i život je život na svakom mjestu kugle zemaljske. (...) Čo-

4 Prilikom jedne od šetnji građana kojima se pridružio njihov domaćin Ićan, ohrabren otvorenim „muškaračkim“ razgovorom i prosvijećenim govorom šjor Karla o bijednim prilikama ovih sela i, s druge strane, „dostojnijem životu kojim žive seljaci po drugim, razvijenijim zemljama“, upita: „- A što vi mislite, šjor Karlo, 'oće li ikad i nama ovđe, po ovijem našim selima, malko svanuti? 'Oćemo li ikad mi ovđe proživjeti tekice bolje, kâ ljudi? “ Ovi neki naši (Zadrani odmah razumješe da tim misli na one koji su otišli u šumu) poručuju: „držte se, izdurajte još ovo malo pa će sve bit drukčije, sve će se to izmijeniti, popraviti“. Na to šjor Karlo odgovara „taktično“: „sve može da bude dobro ako ljudi dobro i pošteno misle. Ako se poštuje vlast, ako svak radi svoj posao, ako je seljak-seljak, činovnik-činovnik, oficiroficir a pop-pop, tad je sve u redu. Ali ako svi hoćemo da komandiramo, ako svi hoćemo da se miješamo u visoku politiku, he, bogami, ja mislim da bi to bila luda kuća u kojoj se ne bi znalo ni ko pije ni ko plaća, i tad nikome ne bi bilo dobro. - Ma i ja sam tako nekako mislio - požuri da se saglasi Ićan. - Gđe je to: motika da piše a pero da kopa! - Ali time nije uspio da sasvim zbriše pobuđeno nepovjerenje." V. Desnica, Zimsko ljetovanje, 101.

42 Desničin bi se postupak mogao čitati i kao razobličavanje postupka reprodukcije ili gradacije Orijenta (nesting Orient), kako ga naziva Milica Bakić-Hayden, „Nesting Orientalism: The Case of Former Yugoslavia“, Slavic Review, 54/1995., br. 4, 917-931. Naime, na tragu promjene percepcije u proizvodnji Drugoga, na koju je uputila Marija Todorova, Imaginarni Balkan (prev. Karmela Cindrić), Zagreb 2015., Bakić-Hayden ukazuje na to da diskurs orijentalizma nije homogen u onoj mjeri u kojoj bi se mogao takvim razumjeti iz Saidova pristupa. Reprodukcija orijentalizma ovdje zapravo znači „nastojanje da svaka regija vidi kulture koje se nalaze južno ili istočno od sebe kao konzervativnije i primitivnije“.

43 Brajovićevo je tumačenje u skladu s perspektivom velikih pisaca koji, izvan okvira vlastitog vremena, pišu za generacije koje dolaze. U zaključku članka tako ističe da bi se Zimsko ljetovanje, Aretej i Prokleta avlija mogli čitati „kao umetnički kodirana ostvarenja koja naročitim vidovima artističkog posredovanja zaklanjaju i zaštićuju svoje, u trenutku publikovanja bar delom subverzivne, po same autore u izvesnoj meri rizične i njihovoj javnoj poziciji kontradiktorne, a u svojoj osnovi izrazito pesimističke, liberalno ironijske vizije sveta, upravo takvim kreativnim strategijama možda pre upućene budućem tumačenju i revidiranom kolektivnom pamćenju/pamćenjima nego ondašnjem, umnogome restriktivnom razumevanju i javnom prihvatanju.“ T. Brajović, „Ironija i kolektivna memorija: Desnica, Krleža, Andrić", 37.

44 V. Desnica, Zimsko ljetovanje, 69. 
vjek, na koncu konca, može da doživi u Smiljevcima ili u Žagrovcu neke čudne i neobjašnjive stvari i da dođe u svakakve situacije, ne manje nego u San Francisku ili Jokohami. ${ }^{\text {“45 }}$.

Stoga bismo ovaj roman trebali čitati izvan granica kojima se u fokus postavlja rahla granica morlačkog življa. Koncepti prema kojima usmjerava svoj interes svakako su temeljni, ljudski, antropološki, u smislu modernističkog interesa za mehanizme funkcioniranja zajednice $^{46}$. Pri tom su, kako je vidljivo, i inherentno politički jer u konačnici apostrofiraju koncept zajednice - $\mathrm{i}$ to u smislu njezina kritičkog promišljanja, posebno u razlici između načela koja se propagiraju i društvene stvarnosti, svakodnevice u kojoj se živi. Njegova kritika implicitno postavlja pitanje mogućnosti ostvarivanja jednakosti u društvu koje propagira jednakost; pitanje potisnutih i jasno demarkiranih razlika: kineskih zidova kojima se opetovano vraća i u romanu i u kasnijem osvrtu na njegovu recepciju. Njegovi su građani/ Zadrani slika onog svijeta koji se, kako sam ističe u eseju O jednom gradu i o jednoj knjizi, razvio u formi istaknutog urbaniteta, „daleko više nego ma koji od ostalih dalmatinskih gradova“4 ${ }^{\text {“7 }}$. Taj je razvoj značio i zatvorenost, hermetičnost, strogo izbrušena društvena pravila, konvencije i uski pogled na svijet ograničen na gradski trg, agoru, kao pozornicu života. Kulise grada i vizuali uskih uličica za Desnicu su odredili i steriliziranost koja je onemogućavala „da se probije na božji dan ni najtananija travčica, kao blijeda i beskrvna afirmacija slobodne prirode i slobodnog života““ ${ }^{48}$ Taj „nesumnjivo najgradskiji i najgrađanskiji ambijenat kod nas“ i jedan od najgrađanskijih ambijenata „evropskog Zapada“49 $\mathrm{u}$ romanu postaje uporište isključive politike koja na modeliranju binarizama gradi hijerarhijske strukture, utemeljujući supremaciju i kolonijalni patronat nad potčinjenim skupinama.

Šireći djelokrug svog teksta na vrijeme i prostor koji nadilaze odrednice samog romana, Desnica je ovim svojim tekstom, ne slučajno, pogodio neuralgijske točke mladog, poslijeratnog poretka koji je svoju ideologiju zasnovao upravo na savladavanju ili negiranju ovakvih društvenih mehanizama ${ }^{50}$. Stoga su kritički angažman i politička progresivnost, a ne „objektivnost“, „,neideologičnost“ ili pesimizam Zimskog ljetovanja bili uzorokom promptnih i glasnih negativnih kritika koje su već 1950. godine objavili Joža Horvat i Marin Franičevićs ${ }^{51}$. Ideologizirana kritika, iako brzo korigirana ozbiljnijim i utemeljenijim

45 Isto, 106.

46 Kako navodi Drago Roksandić, Desnica je u razgovoru s Vlatkom Pavletićem isticao svoj interes prema „apstraktnim stvarima u kojima je ljudima bila zbrisana svaka konkretna oznaka, čak i ime (...) i najdalja definiranost i najmanji podatak koji bi mogao da ih u čitaočevoj glavi veže za ma što historično.“ Drago Roksandić, „„... Pisac uvijek ima upravo onoliku slobodu stvaranja koliku sam sebi dozvoli.... Civilna kultura Vladana Desnice poslije 1945. godine“, Desničini susreti 2005. - 2008., 25. Slično je ponovio kasnije Jevti M. Miloviću na pitanje o sredini u koju postavlja radnju svojih proza: „Ja tu ne postavljam granica, znate, ni nacionalnih, a pogotovo regionalnih... Ja tu ne postavljam granica. I mislim da bi mnogi moji junaci mogli živjeti u ma kojoj drugoj zemlji jednako kao i u nas."

47 V. Desnica, Hotimično iskustvo, 134.

48 Isto, 135.

49 Isto.

50 Kako pokazuje Maša Kolanović, projekt je stvaranja kulture nakon Drugog svjetskog rata u cjelini bio populistički, pri čemu su nivelacije razlika zapravo rezultirale time da se narod pretvarao u masu. Maša KolAnović, Udarnik! Buntovnik? Potrošač... Popularna kultura i hrvatski roman od socijalizma do tranzicije, Zagreb 2011., 60-61.

51 Dežurni kritičari oglasili su se neuobičajeno brzo nakon objavljivanja romana. Joža Horvat nalazi da je tu „sve jadno, prljavo, sitno, žalosno, mračno, nezanimljivo i nerazumljivo, i život i knjiga o tom životu“ te da „bivaju puste i dosadne stranice, čak i dobrog pisca kad izgubi dodir s rodnom zemljom i ljudima koji žive u njoj“. Joža Horvat, „Vladan Desnica, Zimsko ljetovanje“, Književne novine (Beograd), br. 26, 27. 6. 1950., 23. 
kritičkim tekstovima ${ }^{52}$, zbog svoje promptnosti i isključivosti, pokazuje da je ovaj Desničin roman dotaknuo središnje mjesto utemeljenja i funkcioniranja zajednice koja je, u vremenu objavljivanja romana, motivirana snažnim političkim angažmanom i optimizmom. Objavljujući roman koji odstupa od uobičajenih uzusa poslijeratnog angažmana ${ }^{53}$, Desnica se izlaže - i kasnije opravdava - tvrdnjom po kojoj je cilj romana bio pokazati upravo „zaostalo i nazadno i satrveno selo" ${ }^{44} \mathrm{~s}$ jedne te malograđanski komoditet, distanciranost $\mathrm{i}$ inerciju s druge strane. Njegov se angažman, slično npr. kasnijem burlesknom sučeljavanju ideala i realnosti socijalističke svakodnevice u dramskom opusu Ive Brešana, profilirao kao jasan znak kritičke refleksije vlastitog vremena. Ako ga suvremenim čitanjima oslobodimo izmještanja u fiktivni „univerzalistički“ i od svake „ideologije“ oslobođen estetski znak - postaje jasnija važna uloga koju je ovaj roman imao pedesetih godina i nakon njih, u razmicanju granice „ispravnog“ govorenja i pisanja, usložnjavanju dinamike književnog i kulturnog polja, na sličan način na koji su to tada činili autori poput Petra Šegedina ili Miroslava Krleže $e^{55}$. Time istovremeno otvaramo prostor reaktualizacije ovog romana u današnjem vremenu obilježenom borbom $s$ više ili manje materijaliziranim „kineskim zidovima" - bilo da su sastavljeni od stereotipa, kulurnih i socijalnih praksi ili službenih politika koje stvaraju nove, žicom omeđene granice.

\section{$\cos$}

\section{“Separated by a Chinese Wall”. The politics of IDENTITY, INEQUALITY, AND EXCLUSION IN DESNICA'S Zimsko ljetovanje [Midwinter Summer Holiday]}

Standard readings of Vladan Desnica's Zimsko ljetovanje [Midwinter summer holiday] are as a novel of "the conflict of mentalities", an obvious example of the author's verismo [realism], a product of his yearning for "authenticity and objectivity" (K. Nemec) or, in more recent interpretations (e.g. D. Dukić, M. Sindičić Sabljo), as imagologically interesting, but as ultimately expressing a modernism superimposed on visible identitarian poles, as “ideologically neutral” (Z. Kravar), and as an expression of a "pessimistic, liberal, ironising vision of the world" (T. Brajović), destined to meet with an adequate reception only decades after its initial publication.

52 V. Desnica, Hotimično iskustvo, 133.

53 Usp. K. Nemec, Povijest hrvatskog romana, 5-23; M. Kolanović, Udarnik! Buntovnik? Potrošač, 60-61.

54 V. Desnica, Hotimično iskustvo, 136.

55 Šegedinov referat $O$ našoj kritici, kojim je nastupio na Drugom kongresu 1949. godine, i Krležin govor na Trećemu kongresu Saveza književnika Jugoslavije 1952. smatraju se ovjeravanjem raskida sa socrealističkom idejom umjetnosti i prijeratnog sukoba na književnoj ljevici. Usp. Stanko Lasıć, Sukob na književnoj ljevici 1928.-1952. godine, Zagreb 1970. Pedesete godine obilježila je, u cjelini, nova „Živost“ s kojom se povezuje časopis Krugovi (1952. - 1958.), ali i niz značajnih književnih tekstova poput: 1952. Sablasti u dvorcu M. Begovića, Kurlani M. Božića i Djetinjstvo u Agramu M. Krleže, 1953. Hrvatsko glumište B. Gavelle i Ruke R. Marinkovića, 1954. Prokleta avlija I. Andrića, Divota prašine V. Kaleba, Komorna muzika S. Mihalića i Žedan kamen na studencu T. Ujevića, 1955. Izgubljeni zavičaj S. Novaka, 1956. Aleja poslije svečanosti i Odron I. Slamniga i dr. Usp. Maša Kolanović, „Od kulture za mase do masovne kulture“, Refleksije vremena 1945-1955. Katalog izložbe (ur. Jasmina Bavoljak), Zagreb 2012., 179. 
By contrast, in this paper, attention is drawn to the author's clearly stated intentions and views, which are expressive of his detail-oriented focus on disclosing individual and collective stereotyping, the internal homogenisation of privileged groups, and the exclusion of subaltern ones (the peasantry, the Morlachs), resulting in his evident commitment. This is what produced the text's significant aesthetic and political effect at the time it was created and published. The views of the authors of the above-mentioned papers are fully discussed: their investigation of the importance of collective identities (ethnic, confessional, political, sociocultural) within the novel, narrative irony, the disclosure of petty bourgeois opportunism and inconvenience as motivational factors driving the characters'actions. From this starting point, the article moves on to look at the author's use of narrative strategies to highlight the mechanisms of distinction that generate inequality and unjust social relations at both the individual and the collective level. These are revealed in the novel through the focalisation of the characters, their interaction, and, ultimately, in how the central narrative movement of the text is brought to fruition. If, in this regard, we trace the consciously thought-out narrative paths used by Desnica to describe the strategies of building and maintaining "Chinese walls", binary distinctions and colonial discourse, from everyday behaviour to the practices of naming, mastery, and entrenching domination in public discourse, we can read the novel as expressive of the author's cultural and social engagement and far from any supposed neutrality. The humour characteristic of Desnica's text is often generated through focalisation, as the characters' way of viewing the peasantry betrays analogies to the vocabulary and concepts of white colonialism: there is reference to "tribal headsmen or chiefs", bestiality, and "Morlachery" as viewed through "the eyes of the white man". The narrative use of mimicry in focalisation and naming-practices, presented in the book as politically coloured and of socio-cultural significance, operates on a variety of levels: in the descriptions and investigation of exclusion, exoticisation, and the marking of the other, and in the discreet commentary, often delivered in the text "in passing" or as representing the "just so". The processes of bestialisation and denomination are reciprocal strategies and present as elements integrated both into the individual imaginary and in collective representations and symbolic social practices, which may, in the end, be instrumentalised by both the civilian and military authorities. (Re)naming is, in this regard, a strategy related to the appropriation of space and the disciplining and subordination of the populace, one which helps make clear how stereotypes are incorporated into colonial politics. In his treatment of urbicide, wartime destruction, and the crisis of humanity in Zimsko ljetovanje, Desnica drew the reader's attention to the production of binary polarities, essentialisation and Orientalism as instruments of hegemonic structures of authority, enervating the neuralgic points of the contemporary social order. Given its renewed relevance today, this text once again opens up possibilities for critical reflection on the contemporary politics of identity, inequality, and exclusion.

Key words: Midwinter Summer Holiday, Vladan Desnica, Orientalism, hegemony, Morlachs, Croatian literature, identity, imperialism

\section{$\cos$}

\section{Literatura}

Milica Bakić-Hayden, „Nesting Orientalism: The Case of Former Yugoslavia“, Slavic Review, 54/1995., br. 4, 917-931.

Vladimir Biti, Doba svjedočenja. Tvorba identiteta u suvremenoj hrvatskoj prozi, Zagreb 2005., 135-171.

Tihomir Brajović, „Ironija i kolektivna memorija: Desnica, Krleža, Andrićc, Desničini susreti 2005. - 2008. Zbornik radova (ur. Drago Roksandić i Ivana Cvijović Javorina), Zagreb 2010., $31-156$. 
Matthew Cole i Kate Stewart, Our Children and Other Animals. The Cultural Construction of Human-Animal Relations in Childhood, Ashgate 2014.

Vladan Desnica, „O jednom gradu i o jednoj knjizi“, Zadarska revija, 3/1954., br. 1, 21-28.

Vladan Desnica, Hotimično iskustvo: diskurzivna proza Vladana Desnice (prir. Dušan Marinković), Zagreb 2005.

Vladan Desnica, Zimsko ljetovanje, Zagreb 1998.

Davor Dukıć, „Nekoliko imagoloških opaski o Zimskom ljetovanju i Desničinim susretima“, Desničini susreti 2005. - 2008. Zbornik radova (ur. Drago Roksandić i Ivana Cvijović Javorina), Zagreb 2010., 149-156.

Marin Franičević, „Zimsko ljetovanje Vladana Desnice“, Republika, 6/1950., br. 7, 456-457.; Progutane polemike (ur. Jovan Radulović), Beograd 2001., 112-116.

Joža Horvat, „Vladan Desnica, Zimsko ljetovanje“, Književne novine (Beograd), br. 26, 27. 6. 1950., 23; Progutane polemike (ur. Jovan Radulović), Beograd 2001., 110-111.

Maša Kolanović, „Od kulture za mase do masovne kulture“, Refleksije vremena 1945-1955. Katalog izložbe (ur. Jasmina Bavoljak), Zagreb 2012., 166-179.

Maša Kolanović, Udarnik! Buntovnik? Potrošač... Popularna kultura i hrvatski roman od socijalizma do tranzicije, Zagreb 2011.

Zoran Kravar, „Zimsko ljetovanje Vladana Desnice pod ideološkokritičkim lećama“, Desničini susreti 2005. - 2008. Zbornik radova (ur. Drago Roksandić i Ivana Cvijović Javorina), Zagreb 2010., 9-17.

Stanko Lasić, Sukob na književnoj ljevici 1928.-1952. godine, Zagreb 1970.

Krešimir Nemec, Povijest hrvatskog romana od 1945. do 2000., Zagreb 2003.

Marina Protrka Štimec, „'Ovo tursko i iracionalno’. Orijent kao bolest, otrov i lijek u Travničkoj hronici Ive Andrića. “, Mjesto, granica, identitet. Prostor u hrvatskoj književnosti i kulturi (ur. Lana Molvarec), Zagreb 2014., 129-146.

Drago RoksAndić, „’... Pisac uvijek ima upravo onoliku slobodu stvaranja koliku sam sebi dozvoli.... Civilna kultura Vladana Desnice poslije 1945. godine“, Desničini susreti 2005. - 2008. Zbornik radova (ur. Drago Roksandić i Ivana Cvijović Javorina), Zagreb 2010., 18-30.

Edward SAID, Orijentalizam (prev. Biljana Romić), Zagreb 1999.

Mirna Sindičić Sabljo, „Predodžbe o ruralnoj sredini u Zimskom ljetovanju Vladana Desnice“, Fluminensia, 23/2011., br. 1, 131-142.

Marija Todorova, Imaginarni Balkan (prev. Karmela Cindrić), Zagreb 2015.

Couse Venn, Occidentalism. Modernity and Subjectivity, London 2000. 